BIOTECHNOLOGY

\title{
The Study of stimulating effect of metalocomplexes on the basis of hexamethylenamine and DMSO on agricultural crops
}

\author{
V. V. Sukhoveev, G. G. Senchenko, S. A. Priplavko, G. A. Kovtun*, S. P. Ponomarenko*
}

Nizhyn State University named after Mykola Gogol

2, Kropyvyansky Str., Nizhyn, 16000, Ukraine

* The Institute of Bioorganic Chemistry and Petrochemistry NAS of Ukraine

50, Kharkivske Shosse, Kyiv, 02160, Ukraine

e-mail: sukhoveev@ndpu.net

The present work summarizes field researches on stimulating effect of metalocomplex compounds based on urotropin and dimethyl sulfoxide (DMSO) on agricultural crops. It has been shown that these compounds are the effective growth stimulators influencing germinating and crop capacities.

Key words: stimulating effect, metalocomplex, crop, germination.

Introduction. The tendency to increase the amount of new physiologically active substances for agriculture is observed in Ukraine nowadays [1]. The application of metal-containing growth stimulators which are able to intensify biological functions of plants at insignificant concentrations is a perspective direction in this area [2]. Metalocomplex (biocoordinate) compounds correspond to these requirements as they show multifunctional

\footnotetext{
(C) V. V. SUKHOVEEV, G. G. SENCHENKO, S. A. PRIPLAVKO, G. A. KOVTUN, S. P. PONOMARENKO, 2006
}

properties [2-16]. Their effectiveness is higher at low concentrations comparing to that of ions of metal and organic molecules that compose them [17]. Besides, coordinate compounds provide the plants with microelements which they lack in the ground [18]. Complex compounds are not phytotoxic, have a wide action spectrum, and the main thing is that they are not toxic for the warm-blooded animals[2].

A great number of experimental works investigating physiological properties of metalocomplexes have been published, which are generalized in [2-8]. Systematic investigations on studying "structure-activity" 
dependence were performed [5]. It was discovered that the effectiveness of metalocomplexes biological activity is determined by the nature of metal, ligand environment, and the concentration. However, only an insignificant number of works was dedicated to the study of the stimulating effect of metalocmplexes based on urotropin and dimethyl sulfoxide (DMSO) on plants [16, 17, 19-32].

The aim of our work was the investigation of stimulating effect of the mentioned metalocomplexes on germinating capacity and crop productivity of agricultural plants.

Materials and Methods. Earlier obtained metalocomplexes based on urotropin were of general formula:

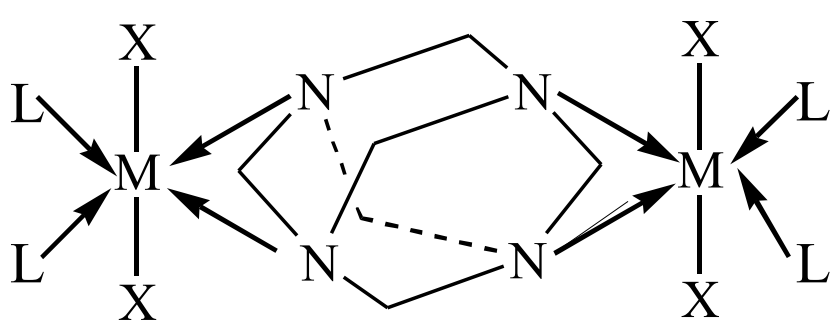

where $\mathrm{M}$ : $\mathrm{Co}(\mathrm{CB}-10)$; $\mathrm{Cu}(\mathrm{CB}-11)$; $\mathrm{Mn}(\mathrm{CB}-12)$; $\mathrm{Sn}$ (CB-13); $\mathrm{Mg}$ (CB-14); Ni (CB-15); $\mathrm{Ba}(\mathrm{CB}-16)$; and $\mathrm{L}$ - DMSO.

It was shown [20-32] that these metalocomplexes stimulate effectively the processes of germination of grain-crops, vegetables, and melons, and in their action they exceed a well-known stimulator Emistym. Laboratory researches were performed according to the modified method of determining growth regulators of root system and above-ground part [33]. Physiological action of substances was investigated in the concentrations of $10^{-2}-$ $10^{-5}$ percentage (p.c.) $[24,25]$. Statistics was calculated by the method [33]. Standard error was in the range of $0.5-2.5 \%$.

In accordance with laboratory results [17, 20-32] of the Department of Chemical Regulation of Plant Growth and Development of The Institute of Bioorganic Chemistry and Petrochemistry of NAS of Ukraine, the following compounds CB-10 (Slavutych), CB-12 (Crystalin), and CB-16 (Oksamyt) were recommended for field testing [34, $35]$.

Well-known growth stimulators Emistym C, Betastymulin and Agrostymulin were chosen as etalons for researching growth regulators. The field tests were performed on winter wheat, rice and sugar beets. Winter wheat researches were performed in the Ukrainian State
Scientific Research and Project Technological Institute on Prognosis and Distant Probing of Agronomic Resources [34], Cherkasy, Chernihiv, Volyn Institutes of Agroindustrial manufacture (AIM), Vinnytsia, Poltava, Podillya, Genichevsk agricultural research stations [34], Nizhyn Sort Research station and agrocompany "Nizhyn". The experiments were performed in accordance with the requirements of B.A. Dospehov's method [34], the fields with equated agricultural background, including typical for winter wheat predecessors, and the sorts registered in State Registry were used. The experimental area of most of scientific institutions was $30-50 \mathrm{~m}^{2}$ each, the experiments were repeated 4 times. Crop predecessors, fertilizers, and sorts of winter wheat were recommended for local conditions. Winter wheat cultivation was performed according to the requirements for intensive technologies application. The obtained crop yields were processed by the method of variance analysis defining the indices of the least essential difference and research accuracy.

The study on the influence of Slavutych growth regulator on growth and development features of winter wheat crops, productivity, and the quality of grown products was performed at processing of seeds as well as at spraying the crops. The crops grown without growth regulators were accepted as control sample, the crops grown with the processing of seeds by Agrostymulin at the norm of $10 \mathrm{ml}$ per ton of seeds, and at spraying crops the norm was $5 \mathrm{ml}$ per hectare. The seeds were treated by water solutions of these preparations. The spraying of seeds was performed at the stage of entering the tube. At the same time the influence of biostimulators on productivity and quality of winter wheat production at different seeding terms and different depth of covering the seed, at different fertilizer backgrounds and at their connection with pesticides was determined.

The effect of researched complexes on the crop productivity of rice was studied in Kuban State Agrarian University. Field tests on the crop productivity of sugar beets were performed at Ternopil, Poltava and Chercasy research stations [34], Nizhyn State Sort-Researching station and on the station of Nizhyn Agricultural production cooperative (APC) named after Frunse. The influence of abovementioned complexes on germinative capacity of agricultural crops seeds was analyzed at Nizhyn State Sort-Researching station and on the station of Nizhyn APC named after Frunse in 2003 - 2005.

Results and Discussion. The study of effectiveness of growth regulators application on germinative and productivity capacity of winter wheat showed that at the introduction of one of the researched preparations the 


\section{Table 1}

The influence of two-time-application of growth regulators on productivity elements of winter wheat plants (Genichevsk agricultural research station, 2001) [34]

\begin{tabular}{lc|c|c|c}
\hline \multicolumn{1}{c|}{ Variant } & Plant height, cm & $\begin{array}{c}\text { Quantity of productive } \\
\text { stems per 1 m2 }\end{array}$ & Weight of head grain, gr & Weight of 1000 seeds, $\Gamma$ \\
\hline $\begin{array}{l}\text { Control (without } \\
\text { growth regulators) }\end{array}$ & 107,6 & 987 & 1,63 & 39,8 \\
$\begin{array}{l}\text { Agrostymulin, } 10 \mathrm{ml} / \mathrm{t} \\
\text { (processing of seeds) } \\
\text { background }\end{array}$ & 112,6 & 1054 & 1,73 & 40,7 \\
$\begin{array}{l}\text { Background + } \\
\text { Slavutych,10g/hectare }\end{array}$ & 113,1 & 1204 & 1,74 & 41,1 \\
\hline
\end{tabular}

Table 2

The effectiveness of processing winter wheat seeds with growth regulators in combination with shooting spraying (Chernigiv Institute of Agroindustrial manufacture) [34]

\begin{tabular}{|c|c|c|c|c|c|c|c|}
\hline \multirow[b]{2}{*}{ Experiment variant } & \multicolumn{2}{|c|}{ Yield, centner/hectare } & \multicolumn{2}{|c|}{ \pm to the control (2001) } & \multirow{2}{*}{$\begin{array}{l}\text { Average, } \\
\text { centner/ } \\
\text { hectare }\end{array}$} & \multicolumn{2}{|c|}{,+- to the control } \\
\hline & 2000 & 2001 & $\begin{array}{l}\text { centner/ } \\
\text { hectare }\end{array}$ & $\%$ & & $\begin{array}{l}\text { centner/hect } \\
\text { are }\end{array}$ & $\%$ \\
\hline $\begin{array}{l}\text { Control (without growth } \\
\text { regulators) }\end{array}$ & 15,9 & 18,7 & - & - & 17,3 & - & - \\
\hline $\begin{array}{l}\text { Background + } \\
\text { Agrostymulin, } \\
10 \mathrm{ml} / \text { hectare }\end{array}$ & 19,7 & 20,3 & 1,6 & 9 & 20 & 2,7 & 15,6 \\
\hline $\begin{array}{l}\text { Background + Slavutych, } \\
10 \mathrm{~g} / \text { hectare }\end{array}$ & 19,1 & 21,6 & 3,2 & 17,1 & 20,5 & 3,2 & 18,6 \\
\hline
\end{tabular}

plants exceeded the control sample significantly by the coefficient of tillering, the depth of tillering knot position as well as by the quantity of productive stems per crop. The depth of tillering knot position increased in $18-67 \%$ under the influence of the growth regulator. Its average value amounted to $2.4 \mathrm{~cm}$, in the variants of processing seeds with Slavutych $-3.6 \mathrm{~cm}$, and with Agrostymulin $-3.8 \mathrm{~cm}$. It indicates that shooting, treated with biostimulators, have better conditions for wintering.

According to the outcomes of probes (1999-2001) at five scientific institutions (Chercasy, Chernihiv, Volyn Insititutes of AIM, Podillya, Genichevsk agricultural research stations) [34], Nizhyn Sort-Researching station and Nizhyn agro company (2003 - 2005) it was shown that Slavutych has significant influence on the increase of crop productivity of winter wheat [34] (Table 1).
According to Table 1 Slavutych exceeds the effect of Agrostymulin by its main indices and contributes to the increase of the quantity of stems in $22 \%$, of the weight of head seed - in $6.7 \%$, of the weight of the thousand of seeds - in $3.2 \%$ in comparison with the control sample, which has significant influence on the increase of crop productivity of winter wheat.

The outcomes of probes of the effectiveness of processing winter wheat seeds with the growth regulators in the combination with spray ing crops are shown in Table 2.

According to Table 2 spraying winter wheat crops with the preparation Slavutych influences its productivity generally better, than spraying with Agrostymulin. Thus, Slavutych caused crop productivity of winter wheat in 2000 in 3.2 centner per hectare $(20.1 \%)$, in $2001-3.2$ centner per hectare (17.1\%). In two years the average crop increase 
Table 3

The study of the influence of Slavutych preparation on the indices of grain quality at processing winter wheat seeds (Chernigiv Institute of Agroindustrial manufacture)

\begin{tabular}{l|c|c|c|c|c|c}
\hline \multirow{2}{*}{ Experiment variant } & \multicolumn{2}{|c|}{ Cellulose content, $\%$} & \multicolumn{2}{c|}{ Nature, $\mathrm{r}$} & \multicolumn{2}{c}{ Weight of 1000 grains, $\mathrm{r}$} \\
\cline { 2 - 6 } & 2000 & 2001 & 2000 & 2001 & 2000 & 2001 \\
\hline $\begin{array}{l}\text { Control (without } \\
\text { growth regulators) }\end{array}$ & 31,7 & 32,6 & 750 & 775 & 29,8 & 36,9 \\
$\begin{array}{l}\text { Agrostymulin, } 10 \\
\text { ml/t }\end{array}$ & 37,8 & 33,0 & 752 & 778 & 31,1 & 38,9 \\
Slavutych, $10 \mathrm{~g} / \mathrm{t}$ & 36,3 & 32,1 & 747 & 785 & 34 & 39,7 \\
\hline
\end{tabular}

\section{Table 4}

The effectiveness of growth regulator Slavutych at processing winter wheat seeds on different predecessors in 2000 (Genichevsk research station)

\begin{tabular}{|c|c|c|c|c|c|c|}
\hline \multirow{4}{*}{ Experiment variant } & \multicolumn{6}{|c|}{ Wheat predecessor } \\
\hline & \multicolumn{3}{|c|}{ Fallow land } & \multicolumn{3}{|c|}{ Corn for silage } \\
\hline & \multirow{2}{*}{$\begin{array}{c}\text { Yield } \\
\text { centner/hectare }\end{array}$} & \multicolumn{2}{|c|}{ \pm to the control } & \multirow{2}{*}{$\begin{array}{c}\text { Yield } \\
\text { centner/hectare }\end{array}$} & \multicolumn{2}{|c|}{ \pm to the control } \\
\hline & & centner/hectare & $\%$ & & centner/hectare & $\%$ \\
\hline $\begin{array}{l}\text { Control (without } \\
\text { growth regulators) }\end{array}$ & 41,2 & - & - & 36,1 & - & - \\
\hline $\begin{array}{l}\text { Agrostymulin, } 10 \\
\mathrm{ml} / \mathrm{t}\end{array}$ & 43,1 & 1,9 & 4,6 & 39,6 & 3,5 & 9,7 \\
\hline Slavutych, $10 \mathrm{~g} / \mathrm{t}$ & 46,2 & 5 & 12,1 & 36,7 & 0,6 & 1,7 \\
\hline
\end{tabular}

enlarged in 18.6\%. Almost analogous outcomes were obtained by the private agroindustrial enterprise ( $\mathrm{PAE})$ Nizhyn Agrocompany (the crop productivity was observed in 4.1 centner per hectare $(20.2 \%)$ in 2003 , in 3.9 centner per hectare $(17.7 \%)$ in 2004 and in 3.8 centner per hectare $(17.5 \%)$ in 2005).

The researches of the influence of Slavutych preparation on the indices of grain quality (the content of cellulose, nature and weight of 1000 seeds) at the processing of winter wheat seeds before sowing, performed at Chernihiv Institute of AIM in 2000 - 2001, are summarized in Table 3 [34].

According to the given table, at the processing of winter wheat seeds with the Slavutych preparation the content of cellulose increases in $6.4 \%$, nature $-0.5 \%$, weight of 1000 seeds $-10.5 \%$ in comparison with the control sample. Still it has less influence on the content of cellulose than Agrostymulin, it has almost the same influence on the nature, though it exceeds the effect of the latter on the index of the weight of 1000 seeds in $5.3 \%$.
According to the outcomes of probes, performed at the station of the APC Nizhyn Agrocompany, at the processing of seeds in the combination with spraying winter wheat crops, Slavutych preparation exceeded the effect of the control sample in all the indices of grain quality (in the content of cellulose $-11.4 \%$, in the weight of 1000 seeds $-10.6 \%$ ). In two years the average increase of winter wheat crops on the research field enlarged in $18.7 \%$. The researches of the Slavutych preparation influence on the indices of grain quality at the winter wheat seeds processing before sowing showed that it increases the content of cellulose in $8.7 \%$ and the weight of 1000 seeds in $10.2 \%$ in comparison with the control sample.

The researches of the effectiveness of Slavutych preparation on winter wheat crops at different predecessors were performed at Genichevsk agricultural research station. The effectiveness of the preparation was determined at growing winter wheat, sown on the fallow land and corn for silage. The results of experiments are shown in Table 4 [34]. 
Table 5

The influence of processing vegetating plants with researched complexes on the yield structure of rice (sort Spalchyk)

\begin{tabular}{l|c|c|c|c|c}
\hline Composition & Concentration (p.c.) & $\begin{array}{c}\text { Average length of } \\
\text { panicle, cm }\end{array}$ & $\begin{array}{c}\text { Weight of grains of } \\
10 \text { plants, gr }\end{array}$ & $\begin{array}{c}\text { Weight of } 1000 \\
\text { seeds, gr }\end{array}$ & Hollow grains\% \\
\hline CB-10 & $10^{-2}$ & 15,8 & 149,1 & 33,1 & 18,95 \\
CB-12 & $10^{-2}$ & 16,9 & 177,6 & 38,2 & 16,03 \\
CB-16 & $10^{-2}$ & 15,7 & 121,4 & 35,5 & 22,72 \\
Emistym & $10^{-3}$ & 15,5 & 152,0 & 33,4 & 24,16 \\
Control & - & 15,1 & 150,4 & 31,5 & 24,84 \\
\hline
\end{tabular}

Table 6

The study of the influence of processing sugar beet seeds with Krystalin on productivity and obtaining of sugar (Ternopil research station)

\begin{tabular}{|c|c|c|c|c|c|c|}
\hline \multirow{2}{*}{ Variant } & \multirow{2}{*}{$\begin{array}{l}\text { Productivity, } \\
\text { centner/ } \\
\text { hectare }\end{array}$} & \multirow{2}{*}{$\begin{array}{l}\text { Content of } \\
\text { sugar, } \%\end{array}$} & \multirow{2}{*}{ \pm to the control } & \multirow{2}{*}{$\begin{array}{c}\text { Obtainigof } \\
\text { sugar, } \\
\text { centner/hectare }\end{array}$} & \multicolumn{2}{|c|}{ \pm to the control } \\
\hline & & & & & centner/hectare & $\%$ \\
\hline Control & 359 & 18,8 & - & 67,5 & - & - \\
\hline Betastymulin $20 \mathrm{ml} / \mathrm{t}$ & 401 & 18,8 & 0 & 75,4 & 7,9 & 11,7 \\
\hline Krystalin $20 \mathrm{~g} / \mathrm{t}$ & 407 & 18,9 & 0,1 & 76,9 & 9,4 & 13,9 \\
\hline
\end{tabular}

One can make a conclusion out of the data given in Table 4 that the usage of Slavutych is the most effective after fallow land (crop productivity increases in $12.1 \%$ in comparison with the control sample, and in $7.5 \%$ in comparison with the etalon), and the usage of Agrostymulin - after corn for silage (crop productivity increases in 9.75 and $8 \%$ respectively).

The outcomes of probes of the influence of the mentioned complexes in field tests on rice productivity (germinative capacity, accumulation of dry weight, structure of vegetating plants crops) are summarized in Table 5 .

According to Table 5 Emistym and the composition CB-10 effect vegetating rice plants almost on the control level, while the composition CB-12 increases the range of indices (germinative capacity, length of panicle, quantity of grains, weight of 1000 seeds, decreases the percentage of hollow grains). It has significant influence on the productivity of this crop. Thus the average length of panicle increases in $11.9 \%$, weight of seeds out of 10 crops - in $18.1 \%$, weight of 1000 seeds - in $21.3 \%$, and the percentage of hollow seeds decreases in $8.8 \%$.

The study of the influence of the mentioned compositions on the germinative capacity of sugar beet seed was performed in the laboratory [21-23], as well as in field tests [35]. As a result of laboratory researches on germinative capacity of sugar beet seed it was determined that a tape which contains $\mathrm{N}$-oxide of pyridine or $\mathrm{N}$-oxide of pyridine and oxalate acid was the best at sprouting in Petri dishes with the usage of tapes and plants growth regulators. It contributes to germinative capacity of seeds up to $98 \%$ in comparison with 82.7 of the control sample. The usage of the soil for sprouting sugar beet seed decreases this index, while 20-hour-steeping of seeds in the solutions of complex compositions increases sprouting in 10-15\% on average [21-23, 35].

The results of the field tests of the influence of Krystalin on the increase of productivity and sugar-content of sugar beet are summarized in Table 6 [35].

According to Table 6 , this preparation increases the productivity of sugar beet in comparison with the control sample in 48 centner per hectare (13\%), and the obtaining of sugar - in 9.4 centner per hectare $(13.9 \%)$ and it exceeds the well-known growth regulator of sugar beet Betastymulin. While using Krystalin at Nizhyn State Sort-Researching station the average increase of sugar beet crop amounted to 48 centner per hectare (13\%) in 2003; 51 centner per hectare (14\%) in 2004 and 49 centner per 
hectare (12\%) in 2005. The obtaining of sugar increased in 9.4 centner per hectare $(13.9 \%)$ on average in comparison with the control sample.

The outcomes of probes of the influence of the mentioned compositions on the germinative capacity while growing agricultural crops showed that the processing of seeds of vegetables and melons with these preparations at Nizhyn State Sort-Researching station increased field germinative capacity in the range of $15-20 \%$ in comparison with the control sample. Oxamyt preparation showed the highest effectiveness. The processing of seeds, performed on the Nizhyn station of APC named after Frunse, contributed to similar increase of field germinative capacity of vegetables, melons and industrial crops and increased the speed of seed sprouting 1.5 fold in comparison with the control sample. Slavutych and Krystalin made the biggest influence on sprouting of tomatoes and cucumbers, increasing seed sprouting from 12 to $23.5 \%$.

Conclusions. Thus field tests proved that Slavutych has positive influence on grain-crops, increasing productivity and quality of production, enlarging the coefficient of tillering, the depth of tillering knot position and the quantity of productive stems per plant etc. Krystalin increases sugar content and productivity of sugar beets, and Oxamyt betters seed sprouting and stimulates the growth and development of agricultural crops.

According to the main indices the researched compositions exceed the action of known stimulators of plant growth (Emistym C, Betastymulin and Agrostymulin) and can be recommended as new plant growth regulators which will allow extending the assortment of domestically produced ecologically safe growth regulators of agricultural crops, increasing productivity and quality of production.

\author{
В. В. Суховєєв, Г. Г. Сенченко, С. О. Приплавко, Г. О. Ковтун ${ }^{\prime}$, С. П. \\ Пономаренко
}

Дослідження стимулювальної дії на сільськогосподарські культури металокомплексів на основі уротропіну і диметилсульфоксиду

Резюме

Виерше узагальнено польова дослідження із стимулювальної дії на сільськогосподарські культури металокомплексних сполук на основі уротропіну $i$ диметилсульфоксиду. Показано, що згадані речовини спричиняють суттєвий вплив на схожість насіння $і$ врожайність сільськогосподарських культур.

\section{REFFERENCES}

1. Пономаренко С. П. Регуляторы роста растений.-К.: Ин-т биоорг. химии и нефтехимии НАНУ, 2003.-319 c.

2. Бовыкин А.В., Карцев А. М., Омельченко А. М., Ранский А. П., Яиимирский K. Б. Бионеорганическая химия защиты растений.-Днепропетровск: Гортипография, 1991.-284 с.

3. Суховєєв В. В. Гербіцидна та рістрегулююча активність гетероциклічних металокомплексних сполук // Вісн. Тернопільс. педуніверситету, 1997.-С. 24-29.

4. Суховєєв В. В. Металокомплексні сполуки: гербіцидна та рістрегулююча активність // Наук. записки НДПУ. Сер. Природ. науки.-Ніжин, 1997.-С. 126-134.

5. Суховєєв В. В. Металокомплексні сполуки на основі похідних сульфолену-3: біологічна активність // Катализ и нефтехимия. - 2001.-№ 7.-С. 55-62.

6. Суховєєв В. В. Металокомплексні сполуки: фунгіцидна активність // Наук. записки НДПІ ім. М. В. Гоголя.-Ніжин, 1998.-C. $85-100$.

7. Суховєєв В. В., Сенченко Г. Г., Ковтун Г. О. Металокомплекси: фармакологічні властивості.-Київ: Ін-т біоорг. хімії і нафтохімії НАНУ, 1999. $-214 \mathrm{c}$

8. Суховєєв В. В., Москаленко О. В., Ковтун Г. О. Протизношувальні та біологічні властивості органодитіофосфатів металів // Катализ и нефтехимия.-2000.-№ 5-6.-С. 81-87.

9. Ковтун Г. О., Суховєєв В. В. Протизношувальні властивості комплексів металів: зв'язок будови з ефективністю // Укр. хім. журн.-2000.-№ 9.-С. 36-42.

10. Ковтун Г. А., Беренблюм А. С., Моисеев И. И. Металлсодержащие оксиданты к нефтепродуктам.-М.: ЦНИИТЭнефтехим, $1978 .-50 \mathrm{c}$.

11. Ковтун Г. А., Моисеев И. И. Металлокомплексные ингибиторы окисления.-К.: Наукова думка, 1993.-224 с.

12. Ковтун Г. А., Плужников В. А. Химия и технология металлокомплексных стабилизаторов окисления.-К.: Ин-т биоорг. химии и нефтехимии НАНУ, 1994.- $240 \mathrm{c}$.

13. Ковтун Г. А., Плужников В. А. Кислоты Льюиса-стабилизаторы окисления органических соединений.-К.: Ин-т биоорг. химии и нефтехимии НАНУ, 1994.-132 с.

14. Ковтун Г. А., Плужников В. А. Химия ингибиторов окисления органических соединений.-К:. Наукова думка, 1995.-296 c.

15. Суховєєв В. В., Ковтун Г. О. Металокомплексні сполуки на основі похідних сульфолену-3: антиокиснювальна ефективність // Катализ и нефтехимия.-2001.-№ 8.-С. 1-9.

16. Суховєєв В. В., Ковтун Г. О., Приплавко С. О., Пустарнакова Г. $\Phi .$, Сенченко Г. Г. Каталіз обриву ланцюгів окиснення диметилсульфоксиду комплексами металів на основі гексаметилентетраміну // Укр. хім. журн.-2001.-№ 8.-С. 97-99.

17. Суховєєв В. В., Приплавко С. О., Пономаренко С. П., Сенченко Г. Г., тфименко Ю. М., Страшна В. М. Вивчення впливу металокомплексних сполук на основі уротропіну на ріст та розвиток кукурудзи // Наук. записки НДПІ ім. М. В. Гоголя. -Ніжин, $-1998 .-$ С. $81-84$.

18. Анспок П. И. Совершенствование способов применения микроэлементов в растеневодстве // Микроэлементы в биологии и их применение в сельском хозяйстве и медицине. - Самарканд. - 1990. - С. 115-116.

19. А. с. № 1415743 СССР, МКИС 07 F 15/06, А 01 N 55/02 Тетрадиметилсульфоксидгексаметилентетраминбисдихлорид кобальта (II), проявляющий свойства регулятора роста и развития растений табака / Б. И. Иманакунов, Т. Токматов, А. Бердиев и др.-Заявл. 05.05.86 // БИ.-1990.-№ 24.-С. 8.

20. Суховеев В. В., Борейко В. К., Пономаренко С. П., Ковтун Г. А., Сенченко $C$. Г. Синтез и рострегулируюшая активность металлокомплексов на основе уротропина // Тр. конф. ”Перспективы создания экологически безопасных регуляторов 
роста растений, средств защиты и технологий их применения в производстве сельскохозяйственной продукции".-Киев, 1992.-C. 17.

21. Пат. України № 29139 A, MKI C07F15/06, A01N 55/02. Тетрадиметилсульфоксидгексаметилентетрамінбісдихлорид металу для підвищення врожайності сільськогосподарських культур / В. В.Суховєєв, С. П. Пономаренко, С. О.Приплавко, Г. О. Ковтун.-Заявл. 15.01.1998 // Опубл. 16.10.2000.

22. Пат. України № 29138 A, MKI C07F15/06, A01N 55/02. Тетрадиметилсульфоксидгексаметилентетрамінбісдихлорид металу для підвищення врожайності зернових, овочевих, баштанних та технічних культур / В. В.Суховєєв, С. П. Пономаренко, С. О. Приплавко, Г. О. Ковтун.-Заявл. 15.01.1998 // Опубл. 16.10.2000.

23. Пат. України № 30209 А, MKI C07F15/06, А 01N 55/02. Спосіб застосування тетрадиметилсульфоксидгексаметилентетрамінбісдихлорид кобальту (II) для підвищення врожайності сільськогосподарських культур / В. В.Суховєєв, С. П. Пономаренко, С. О. Приплавко, Г. О. Ковтун.-Заявл. 23.01.1998 // Опубл. 15.11.2000.

24. Суховєєв В. В., Приплавко С. О., Сенченко Г. Г., Ковтун Г. О., Пономаренко С. П. Вивчення рістрегулюючої дії металокомплексних сполук на основі уротропіну на ріст та розвиток зернових культур // Фізіологічно активні речовини.-2000.-№ 1 (29).-С. 76-78.

25. Суховєєв В. В., Сенченко Г. Г., Приплавко С. О., Ковтун Г. О., Пономаренко С. П. Дослідження рістрегулюючої дії металокомплексних сполук на основі уротропіну на баштанних культурах // Біол. науки і пробл. рослинництва.-Умань: держ. аграр. ун-т, 2003.-С. 61-65.

26. Суховєєв В. В., Приплавко С. О., Сенченко Г. Г., Білогор С. В., Суховєєв О. В., Олешко Ю. М. Дослідження коренеутворюючої дії металокомплексів на основі уротропіну // Праці наук.-практ. конф. „Природничі науки на межі століть”.-Ніжин, 2004.-С. 130.

27. Суховєєв В. В., Приплавко С. О., Пономаренко С. П., Лофицька Л. М., Сенченко Г. Г. Вплив мікроелементів на ріст та розвиток проростків пшениці // Праці Х з'їзду Укр. бот. т-ва.-Київ; Полтава, 1997.-С. 251.

28. Суховєєв В. В., Приплавко С. О., Пономаренко С. П., Сенченко Г. Г., Лисенко Л. І. Вивчення залежності рістрегулюючої активності уротропінових комплексів від природи органічного ліганду та іону металу // Праці XVIII Укр. конф. 3 орг. хімії.-Дніпропетровськ, 1998.-С. 429.

29. Суховеев В. В., Приплавко С. А., Сенченко Г. Г. Исследование зависимости рострегулирующей активности от структуры металлокомплексных соединений на основе гексаметилентетрамина // Труды VI Междунар. конф. "Регуляторы роста и развития растений в биотехнологиях".-Москва: МСХА, 2001.-C. 125-126.
30. Суховєєв В. В., Приплавко С. О., Сенченко Г. Г., Ковтун Г. О., Пономаренко С. П. Дослідження практично-корисних властивостей металокомплексів на основі уротропіну // Праці Укр. конф. "Актуальні питання органічної та елементорганічної хімії і аспекти викладання органічної хімії у вищій школі".-Ніжин: НДПУ, 2002.-С. 49.

31. Суховєєв В. В., Приплавко С. О., Гавій В. М. Металокомплексні сполуки-екологічно безпечні регулятори росту рослин // Праці IV Міжнар. наук. конф. “Охорона навколишнього середовища та раціональне використання природних ресурсів”.-Донецьк: ДонНТУ, 2005.-Т. 2.-С. 178-179.

32. Приплавко С., Сенченко Г., Суховєєв В. Вивчення впливу біометалів, що входять до складу металокомплексів, на ріст і розвиток пшениці // Праці конф. молодих вчених-ботаніків України.-Ніжин, 1999.-С. 125.

33. Жирмунская Н. М., Зубкова Н. Ф., Овсянникова Т. В. и др. Методические рекомендации по проведению лабораторного скрининга синтетических регуляторов роста растений.-Черкассы: отд-ние НИИТЭХИМа, 1985.-29 с.

34. Вивчити ефективність та вдосконалити технологію застосування регуляторів росту рослин нового покоління на посівах озимої пшениці: Звіт про НДР (заключн.) / / Укр. держ. наук.-досл. ін-т по прогнозуванню і дистанційному зондуванню агрохімічних ресурсів (№ ДР 631.452; Інв. № 183.- К., 2001. $-74 \mathrm{c}$.

35. Розробка технології застосування біостимуляторів нового покоління на польових культурах з метою підвищення продуктивності ріллі та зниження собівартості продукції: Звіт про НДР (заключн.) / / Укр. держ. наук.-досл. ін-т по прогнозуванню і дистанційному зондуванню агрохімічних ресурсів (№ ДР 631.452; Інв. № 183). - К., 1998. - 229 с

УДК 541.49:577.15/17:632.954 Надійшла до редакції 11.11.04 